\title{
Projected river discharge in the Euphrates-Tigris Basin from a hydrological discharge model forced with RCM and GCM outputs
}

\author{
Deniz Bozkurt ${ }^{1,2,3, *}$, Omer Lutfi Sen ${ }^{2}$, Stefan Hagemann ${ }^{3}$ \\ ${ }^{1}$ University of Chile, Department of Geophysics, Center for Climate and Resilience Research (CR)2, Santiago, Chile \\ ${ }^{2}$ Istanbul Technical University, Eurasia Institute of Earth Sciences, Istanbul, Turkey \\ ${ }^{3}$ Max Planck Institute for Meteorology, Hamburg, Germany
}

\begin{abstract}
The hydrological discharge (HD) model of Max Planck Institute for Meteorology is forced by a variety of climate model datasets to investigate the future of discharge in the Euphrates-Tigris Basin. The data include daily time series of surface runoff and sub-surface runoff outputs of 2 global climate models (GCMs) (the SRES A1B scenario simulation of ECHAM5/MPIOM and the RCP 4.5 scenario simulation of MPI-ESM-LR) and the dynamically downscaled outputs of ECHAM5/MPIOM and NCAR-CCSM3 scenario (SRES A1FI, A2 and B1) simulations. The suite of simulations enables a comprehensive analysis of the projected river discharge, and allows a comparison between CMIP5 simulations of MPI-ESM-LR and CMIP3 results from its predecessor ECHAM5/MPIOM on a basin scale. We demonstrate that HD simulations forced with relatively low-resolution GCM outputs are not good at reproducing the seasonal cycle of discharge, which is typically characterized by less flow in the peak season and an earlier peak in annual discharge. Simulations forced with the MPI-ESM-LR yield more robust information on the annual cycle and timing of the annual peak discharge than ECHAM5-forced simulations. In contrast to GCM-forced simulations, high-resolution RCM-forced simulations reproduce the annual cycle of discharge reasonably well; however, overestimation of discharge during the cold season and bias in the timing of springtime snowmelt peaks persist in the RCM-forced simulations. Different RCM-forced scenario simulations indicate substantial decreases in mean annual discharge for the Euphrates and Tigris Rivers by the end of the century, ranging from 19-58\%. Significant temporal shifts to earlier days ( $3-5 \mathrm{wk}$ by the end of the 21 st century) in the center time of the discharges are also projected for these rivers. As the basin is considered water-stressed and the region is strongly influenced by water-scarcity events, these unfavorable changes may potentially increase water disputes among the basin countries.
\end{abstract}

KEY WORDS: Climate change $\cdot$ Middle East $\cdot$ River discharge $\cdot$ Dynamical downscaling $\cdot$ Regional climate modeling

- Resale or republication not permitted without written consent of the publisher

\section{INTRODUCTION}

Water availability, rather than temperature, is the key climatic determinant for human life in semi-arid areas across the planet (deMenocal 2001). Waterstressed areas with rapid population growth and industrialization, in which the water cycle is dominated by snowmelt hydrology, are expected to be more susceptible to climate change impacts. Being extremely vulnerable to any reductions in available surface and ground water, the Euphrates-Tigris Basin (hereafter ETB), especially Mesopotamia, which is the fertile land between the Euphrates and Tigris Rivers, has been sensitive to climate variability since the beginning of the earliest civilizations. On the one hand, for instance, under favorable climate 
conditions (between 2300 and 2200 BC), the Akkadian Empire dominated over the Mesopotamian region; this domination was linked to the productive but remote rain-fed agricultural lands of northern Mesopotamia and the irrigation of agriculture fields in southern Mesopotamian cities (deMenocal 2001). On the other hand, climatic changes are thought to have punctuated and redirected cultural trajectories in the late prehistoric-early historic eastern Mediterranean and Mesopotamian regions (Weiss et al. 1993, deMenocal 2001, Kaniewski et al. 2010). For instance, a drought hypothesis was developed by Weiss (1982) to explain the Late Bronze Age period of collapse of cities and states from Greece through Mesopotamia to Egypt. Moreover, several studies based on regional paleoenvironmental proxy data have indicated that the striking decrease in rainfall, which is also correlated to minima in the discharge from the Euphrates and Tigris Rivers between 1150 and $950 \mathrm{BC}$, is one of the main reasons for the decline of the Babylonian and Assyrian Empires between 1200 and 900 BC (Brinkman 1968, Kay \& Johnson 1981, Neumann \& Parpola 1987, Alpert \& Neumann 1989, Kaniewski et al. 2010).

In modern civilizations, these rivers have been the focus of international disputes over water availability and use (Daoudy 2004, Gleick 2014). The basin is considered water-stressed, and the region is strongly influenced by water-scarcity events, as ever greater demands are placed on limited water resources through population growth and economic development (Chenoweth et al. 2011). Due to rapid population growth (i.e. the population in this region quadrupled in $55 \mathrm{yr}$, increasing from 46 million in 1950 to 180 million in 2005; United States Census Bureau 2009, International Data Base: www.census.gov/ipc/www/idb/region.php) and industrialization, the renewable water potential per capita per year has been decreasing. Furthermore, the issue of water rights became a point of contention between the major basin countries, Iraq, Syria and Turkey, in the 1960s, when Turkey implemented the Southeastern Anatolian Project, a 30-billion-dollar investment, which aimed to generate energy (GAP-RDA, Güneydoğu Anadolu Projesi-Regional Development Administration home page, Ankara, Turkey, http:// www.gap.gov.tr) and irrigate vast semi-arid plains in southeastern Turkey by constructing 19 hydropower plants and 22 dams. Since that time the amount and quality of the water received by the downstream countries have been reduced. Lastly, the 2008 drought in Iraq and Syria sparked new negotiations between the basin countries over trans- boundary river flow. However, water is still a major point of international contention among the countries in the Middle East, and disputes are expected to intensify in the future as a result of climate change impacts on the region. For instance, in a very recent study, Gleick (2014) assessed the ongoing conflict in Syria and its possible connections to water scarcity, and investigated future climaterelated risks to water systems. Gleick (2014) concluded that without improvements in water management strategies and comprehensive international agreements, water-related factors are likely to produce even greater risks to the local and regional political stability in the basin.

A new assessment report by the Intergovernmental Panel on Climate Change (IPCC) states that human influence on the climate system is clear, and there is no doubt that enhanced greenhouse forcing has led to unequivocal changes in most regions of the globe (IPCC 2013). The Middle East, which lies in the eastern area of the Mediterranean Basin, is one of the most vulnerable regions to global climate change, and a number of regional climate simulations indicate there will be significant large-scale reductions in precipitation in addition to a rise in temperature by the end of the present century (e.g. Önol \& Semazzi 2009, Bozkurt \& Sen 2013, Önol et al. 2014). More specifically, several efforts have been made to determine the climate change impacts on water availability in the ETB. According to a recent study by Voss et al. (2013), the ETB experienced substantial water loss between January 2003 and December 2009, based on measurements of NASA's Gravity Recovery and Climate Experiment (GRACE) satellites. They also demonstrated that most of the water loss was due to reductions in groundwater caused by increased groundwater extraction during and after the 2007 drought. Chenoweth et al. (2011) investigated the likely effects of climate change on the water resources of the eastern Mediterranean and Middle East regions using a high-resolution climate model forced by lateral boundary conditions from the HadCM3, driven by the SRES A1B scenario. They found that the average annual Euphrates-Tigris river discharge may decline by $9.5 \%$ between 2040 and 2069 , with the greatest decline $(12 \%)$ in Turkey, while the decline is estimated at only $4 \%$ in Iraq. They also project further decrease in river discharge by 2070-2099; however, the decrease would be $<1 \%$. Based on these results, the authors concluded that climate change impacts, together with rapid population growth, is likely to reduce per capita water resources considerably in much of the Middle East. 
Bozkurt \& Sen (2013) used dynamically downscaled outputs of different global climate models (GCMs) and emission scenarios to investigate the impacts of future climate changes in the ETB. In their study, a striking impact of warming was detected on the snow water equivalent in the highlands of the basin, which is projected to decrease by $55 \%$ for the B1 scenario, $77-85 \%$ for the A2 scenario and $87 \%$ for the A1FI scenario. Moreover, they found that, within the basin, the territory of Turkey will likely experience the most adverse effects of climate change.

Previous studies have focused on climate change impacts in the ETB mostly by analyzing atmospheric model outputs. To date, only a limited number of studies have been conducted to simulate changes in river discharge in the ETB, with limited datasets and emission scenarios. For instance, Kitoh et al. (2008) used a super-high-resolution GCM and a river flow model to investigate discharge change in the Euphrates River. They reported that annual discharge from the Euphrates River is expected to decrease significantly $(29-73 \%)$ by the end of the century. In a comprehensive 1-way coupling study, we forced the hydrological discharge (HD) model (Hagemann \& Dümenil 1997, Hagemann \& Dümenil Gates 2001) of the Max Planck Institute for Meteorology with a variety of datasets in order to study future river discharge in this basin. The data included the direct output of 2 GCMs - the SRES A1B scenario output of ECHAM5/MPIOM (Roeckner et al. 2003, Jungclaus et al. 2006) and the RCP 4.5 scenario output of MPI-ESM-LR (Jungclaus et al. 2013, Stevens et al. 2013)—and the dynamically downscaled output of ECHAM5/MPIOM and NCAR-CCSM3 simulations based on the SRES A1FI, A2 and B1 scenarios. The subject of the present study is, therefore, 2-fold: (1) we present and evaluate the performance of the HD model in the basin, and (2) we present the projected river discharge for the basin. Moreover, the GCM-forced simulation provides a comparison between the Coupled Model Intercomparison Project (CMIP5) (Taylor et al. 2012) results of MPI-ESM-LR and the World Climate Research Project Coupled Model Intercomparison Project Phase 3 (CMIP3) (Meehl et al. 2007) results of its predecessor ECHAM5/MPIOM, as well as comparisons between the 2 relative to the CMIP3 and CMIP5 ensemble means on a basin scale. In this respect, our study was also able to utilize information from the very recent study by Hagemann et al. (2013), who compared MPI-ESM with its predecessor ECHAM5/MPIOM in terms of land surface water and energy fluxes.

\section{MODEL DESCRIPTION, DATA AND APPROACH}

\subsection{The HD model}

The HD model (Hagemann \& Dümenil Gates 2001) is used to simulate discharge from the output of the GCMs and RCMs used in this study. It is a state-ofthe-art discharge model that is applied and validated on a global scale, and it is also part of the coupled atmosphere-ocean GCMs ECHAM5/MPI-OM and MPI-ESM. It globally simulates lateral freshwater fluxes at the land surface. As a general strategy the HD model computes discharge at a $0.5^{\circ}$ resolution using a daily time step. Daily time series of surface runoff and sub-surface runoff are the input fields required to drive the HD model, where lateral waterflow is separated into the 3 flow processes: overland flow, baseflow and riverflow. Overland flow uses surface runoff as input and represents the fast-flow component within a grid box, baseflow is fed by drainage from the soil and represents the slow-flow component, and the inflow from other grid boxes contributes to riverflow. The sum of the 3 flow processes equals the total outflow from a grid box. The input fields of surface runoff and sub-surface runoff are interpolated from the respective GCM grid to the HD model grid resolution. Although the HD model was originally developed for global-scale applications, input fields provided by RCMs can also be used to drive the model, as done by Hagemann \& Dümenil (1999) for the Baltic Sea catchment and Hagemann \& Jacob (2007) for Europe. RCM fields are interpolated to the $0.5^{\circ} \times 0.5^{\circ} \mathrm{HD}$ model grid, and the model reproduces discharge for the corresponding regional domain.

Besides different lateral flows, another crucial part of the HD model is the drainage network that is based on the land surface topography (Hagemann \& Dümenil 1997). The drainage network, which is controlled by the surface topography, determines the direction of water flow on the surface, as well as the catchment boundaries in the model. In the HD model drainage network, it is assumed that every grid cell drains into the neighboring grid cell with the lowest elevation. A derived drainage network based on the elevation differences should, therefore, match the actual surface river system. The ETB drains an area of approximately $880000 \mathrm{~km}^{2}$, and is characterized by the 2 snow-fed rivers, the Euphrates and Tigris (Fig. 1). The basin is surrounded by the eastern Anatolian mountains of Turkey in the north, from which $90 \%$ of the total annual flow of the Euphrates River stems. The Zagros mountains in the east provide 


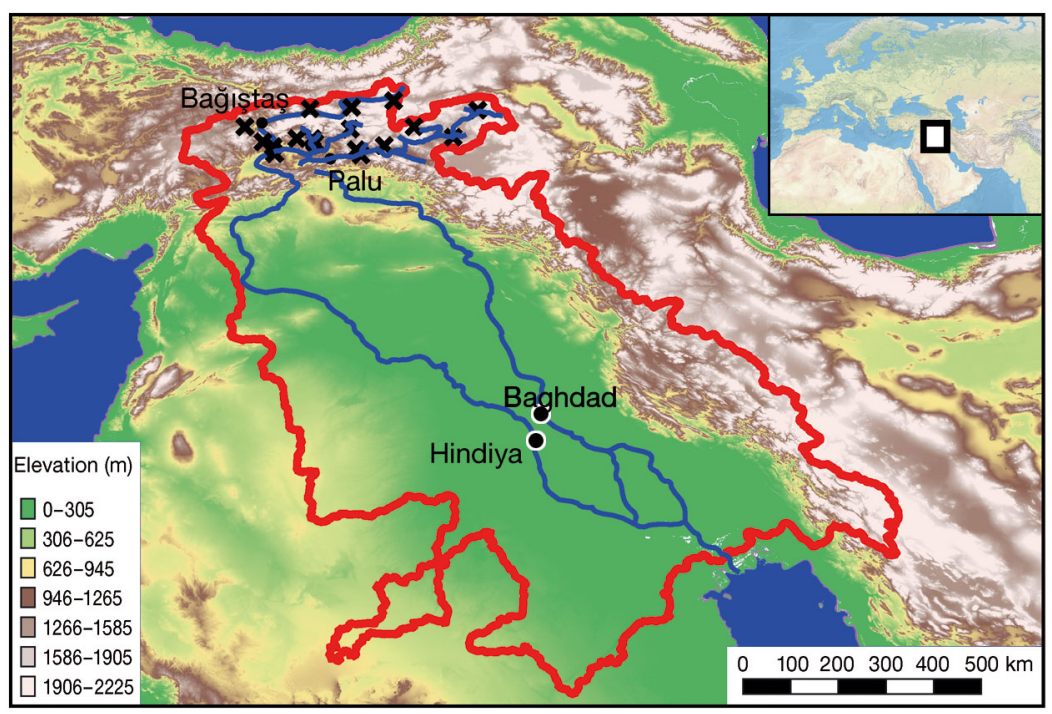

Fig. 1. Euphrates-Tigris Basin (red line) on a digital elevation map derived from global hydrological data and maps based on shuttle elevation derivatives at multiple scales (HydroSHEDS) (Lehner et al. 2008). The river-flow network was obtained with Natural Earth, free vector and raster map data at a 1:50 m scale (http://naturalearthdata.com). Meteorological stations in the upper Euphrates Basin (crosses) and streamflow gauging stations (dots) were used to validate the hydrological discharge model

approximately $50 \%$ of the total annual flow of the Tigris River. More detailed information on the basin, together with general climate characteristics, can be found in Bozkurt \& Sen (2013).

\subsection{Data and approach}

As is stated in the model description section, the actual river direction and its model counterpart must match each other. Therefore, correction of the model river network and catchment boundary was one of our major tasks, as some inconsistencies existed in the rivers' directions. The general procedure used globally to correct river networks is described in Hagemann \& Dümenil (1997), but, for the ETB, manual corrections were conducted based on the actual river flow network obtained with Natural Earth, free vector and raster map data at a 1:50 m scale, in which World Data Bank 2-based rivers were digitized to create single line drainages from double line rivers (http://naturalearthdata.com). All rivers in this database received manual smoothing and position adjustments to fit shaded relief generated from SRTM Plus elevation data, which are more recent and (presumably) more accurate. Daily time series of surface runoff and sub-surface runoff output from various climate model simulations were used to drive the HD model. These comprise 2 GCM simulations (ECHAM5/MPI-OM following the SRES A1B scenario, hereafter GCMECHAM5, and MPI-ESM-LR following the RCP 4.5 scenario) and the dynamically downscaled output of ECHAM5/ MPIOM (SRES A2 scenario), hereafter RCM-ECHAM5, and NCAR-CCSM3 (SRES A1FI, A2 and B1 scenarios), hereafter RCM-CCSM3. For the downscaling, the RCM, RegCM3 (Pal et al. 2007), was used. Furthermore, dynamically downscaled output of the NCEP/ NCAR reanalysis data, hereafter RCMNCEP/NCAR, were used to drive the HD model for the reference period. The RCM simulations have a $27 \mathrm{~km}$ horizontal resolution, resulting in $144 \times 100$ grid points for the eastern Mediterranean-Black Sea region. The RCM includes (1) the land surface model BATS (Bioshphere-Atmosphere Transfer Scheme; Dickinson et al. 1993); (2) the non-local boundary layer scheme of Holtslag et al. (1990); (3) the radiative transfer package of CCM3 (Community Climate Model Version 3; Kiehl et al. 1996); (4) the ocean surface flux parameterization of Zeng et al. (1998); and (5) a simplified version of the explicit moisture scheme of Hsie et al. (1998); (6) a large-scale cloud and precipitation scheme that accounts for the subgrid scale variability of clouds (Pal et al. 2000); and (7) Grell (1993) with Fritsch \& Chappell (1980) closure for a cumulus convection scheme. Detailed descriptions of physical parameterizations and the RegCM3 model can be found in Pal et al. (2007). All RCM simulations were accomplished in Turkey under a project of the United Nations Development Programme (UNDP) entitled 'Enhancing the Capacity of Turkey to Adapt to Climate Change'. Information on the models and simulations and evaluation of the reference period and performance of the RegCM3 in simulating the general climate characteristics of the region are given in detail in Bozkurt et al. (2012). Bozkurt and coworkers report that RCM simulations forced by GCM output reproduce the regional climate fairly well. RCM-CCSM3 simulation, however, produces drier and warmer conditions than the observations, especially during the summer season for the model domain. For the RCM, they state that RegCM3 is capable of reproducing precipitation and surface temperatures, as well as the upper level fields. On the other hand, they report that reanalysis 
simulation tends to overestimate precipitation in the mountainous areas of the eastern MediterraneanBlack Sea region. The storylines of the SRES emission scenarios can be found in Nakicenovic et al. (2000). The properties of all the datasets used to force the HD model are summarized in Table 1.

MPI-ESM-LR (Max Planck Institute for Meteorology-Earth System Model-Low Resolution), hereafter MPI-ESM, is a coupled earth system model. It employs coupling of the atmosphere, ocean and land surface through energy, momentum, water and important exchanges of trace gases. It includes ECHAM6 in the atmosphere at T63 (about $1.875^{\circ}$ ) resolution (Stevens et al. 2013), MPI-OM in the ocean at approximately $1.6^{\circ}$ resolution with 40 vertical layers (Jungclaus et al. 2013) and JSBACH for land surfaces (Brovkin et al. 2009, 2013). The RCP 4.5 scenario of MPI-ESM was used to drive the HD model; this corresponds to a stabilization scenario in which total radiative forcing is stabilized before 2100 via mitigation methods, such as the employment of a range of technologies and strategies to reduce greenhouse gas emissions (Clarke et al. 2007). Detailed information on the RCPs can be found in Moss et al. (2010).

Daily surface runoff and sub-surface runoff from both GCM and RCM outputs are interpolated using conservative remapping to the standard HD model grid $\left(0.5^{\circ} \times 0.5^{\circ}\right)$ so that mass balances are kept. For all cases, $30 \mathrm{yr}$ control climate simulations of the present climate are validated against observations (Section 3). Finally, in terms of climate change impacts on river discharge in the ETB, differences between future and reference periods are presented in Section 4.

Table 1. Information about the datasets that are used to force the Hydrological discharge (HD) model

\begin{tabular}{|llllll|}
\hline & $\begin{array}{l}\text { GCM / GCM } \\
\text { Forcing for } \\
\text { RegCM3 }\end{array}$ & \multicolumn{2}{c}{ Resolution } \\
Spatial & Vertical & Scenario & Period \\
\hline GCM & ECHAM5/MPIOM & T63 $\left(1.875^{\circ}\right)$ & L31 & Historical & 1961-1990 \\
& & & & SRES A1B & $2071-2100$ \\
& MPI-ESM-LR & T63 (1.875 $)$ & L47 & Historical & $1971-2000$ \\
& & & & RCP 4.5 & $2071-2100$ \\
GCM & NCEP/NCAR & $27 \mathrm{~km}$ & L18 & Historical & $1961-1990$ \\
Forced & ECHAM5/MPIOM & $27 \mathrm{~km}$ & L18 & Historical & $1961-1990$ \\
RegCM3 & & & & SRES A2 & $2040-2100$ \\
& & & & SRES B1 & $2040-2100$ \\
& NCAR-CCSM3 & $27 \mathrm{~km}$ & L18 & Historical & $1961-1990$ \\
& & & & SRES A2 & $2040-2100$ \\
& & & & SRES A1F1 & $2040-2100$ \\
& & & & SRES B1 & $2040-2100$ \\
\hline
\end{tabular}

\section{EVALUATION OF SIMULATED DISCHARGE}

In terms of reference period simulations, $30 \mathrm{yr}$ daily surface runoff and sub-surface runoff from the GCMs, GCM-ECHAM5 (1961-1990) and MPI-ESM (1971-2000) and from the dynamically downscaled outputs of RCM-ECHAM5 (1961-1990), RCM-CCSM3 (1961-1990) and RCM-NCEP/NCAR (1961-1990) were used to drive the HD model. In order to validate the simulation results against observations, 4 streamflow gauging stations were used (see Fig. 1). Fig. 1 also shows meteorological stations in the upper Euphrates Basin, whose data were obtained from the Turkish State Meteorological Service. Information on the gauging stations is given in Table 2. Since the availability of discharge measurements differs among the stations, validation is based on different periods of time for the individual gauging stations.

Fig. 2 shows the mean annual discharge cycle of the Palu, Bağıştaş, Baghdad and Hindiya streamflow gauging stations, together with the HD model simulations forced by GCM outputs (GCM-ECHAM5, MPIESM) and RCM outputs (RCM-NCEP/NCAR, RCMECHAM5, RCM-CCSM3). Comparisons were carried out between the station point and corresponding HD model grid $\left(0.5^{\circ} \times 0.5^{\circ}\right)$ without any interpolation. Peak discharge is shown in April for Palu and Baghdad and in May for Bağıştaş and Hindiya, indicating typical snow-fed river characteristics in this region. In general, the characteristics of snow-fed rivers are reproduced by the HD model in GCM- and RCMforced cases. In terms of GCM-forced simulations, both models reproduce smaller magnitudes than the observed discharge. GCM-ECHAM5 simulations show less flow in the peak season, and annual peak discharge takes place earlier in the year than indicated by observations. Simulations with MPI-ESM yield a better match to observations, especially for peak seasonal discharge. In contrast to GCMforced simulations, RCM-forced simulations reproduce the annual cycle of discharge reasonably well. Overestimation of the peak discharge and bias in the timing of the springtime snowmelt peak of discharge persist in RCM-NCEP/NCAR and RCMECHAM5 simulations. In both simulations, the discharge bias tends to be greater in the peak season for smaller drainage areas (e.g. Palu and Bağıştaş). RCM-CCSM3 simulations 
Table 2. Information about the 4 streamflow gauging stations considered in the basin

\begin{tabular}{|lccc|}
\hline $\begin{array}{l}\text { Station } \\
\text { name }\end{array}$ & Coordinates & $\begin{array}{c}\text { Altitude } \\
(\mathrm{m})\end{array}$ & $\begin{array}{c}\text { Drainage } \\
\text { area }\left(\mathrm{km}^{2}\right)\end{array}$ \\
\hline Palu & $38.69^{\circ} \mathrm{N}, 39.93^{\circ} \mathrm{E}$ & 852 & 25515 \\
Bağıştaş & $39.43^{\circ} \mathrm{N}, 38.45^{\circ} \mathrm{E}$ & 865 & 15562 \\
Baghdad & $33.30^{\circ} \mathrm{N}, 44.38^{\circ} \mathrm{E}$ & 30 & 134000 \\
Hindiya & $32.72^{\circ} \mathrm{N}, 44.27^{\circ} \mathrm{E}$ & 28 & 274100 \\
\hline
\end{tabular}

yield discharge of a smaller magnitude, which better matches the peak season. However, it should be noted that the dynamically downscaled RCM-CCSM3 simulation underestimates precipitation in all seasons other than winter, which is most likely a result of the dryness in the upper levels of the raw CCSM3 outputs (Bozkurt et al. 2012).

A general bias in the representation of the annual cycle and timing of the annual peak discharge in the GCM-forced simulations is most likely caused by shortcomings in the GCM fields. Since the surface orography is a critical factor for the precipitation distribution in the highlands of the ETB, the coarse resolution of GCMs may not allow adequate representation of the spatial distribution of precipitation, especially in the upper parts of the basin. Indeed, a comparison of 30 yr average annual precipitation distributions from the Climatic Research Unit (CRU) observational dataset, the MPI-ESM and the GCMECHAM5 indicates drier conditions in the GCMECHAM5 over the upper parts of the basin, which is characterized by mountains (Fig. 3). In contrast, the RCM-forced simulations capture the spatial pattern of precipitation well; however, overestimation seems to occur for the mountainous areas. This overestimation could be related to problems with the RCM itself (i.e. RegCM3), but may also be caused by the number of stations being insufficient, especially in mountainous areas, potentially yielding lower precipitation quantities in the CRU data than true values (Bozkurt et al. 2012).

In order to show how the selected GCM-ECHAM5 and MPI-ESM spread among the CMIP3 and CMIP5 simulations, we compared the monthly mean precipitation cycle of GCM-ECHAM5 and MPI-ESM in the ETB to those based on the CMIP3 and CMIP5 simulations for the period 1961-1990, along with observed values (Fig. 4). The mean annual cycle of precipitation is well represented in the CMIP3 ensemble; however, there is a discernible dry bias in the cold season (November-May). Compared to the CMIP3 ensemble, the GCM-ECHAM5 simulation shows even greater dryness, which is more pronounced in spring
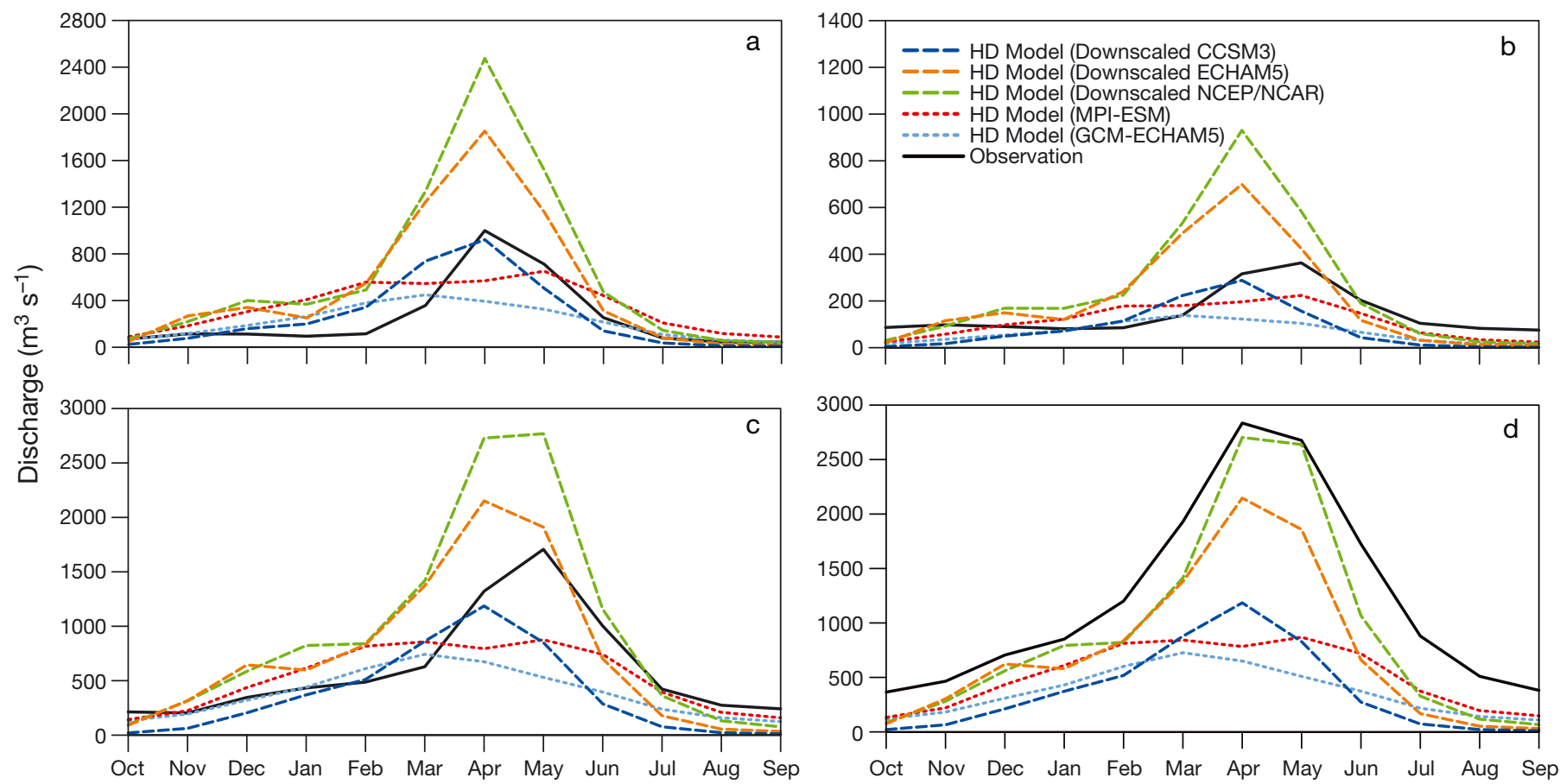

Fig. 2. Mean monthly discharge for the (a) Palu, (b) Bağıştaş, (c) Hindiya and (b) Baghdad streamflow gauging stations (black continuous line) and the HD model simulation results (dashed lines) forced by GCM-ECHAM5 (blue), MPI-ESM (red), RCM-NCEP/NCAR (orange), RCM-ECHAM5 (green) and RCM-CCSM3 (dark blue). Note differences in $y$-axis scales 

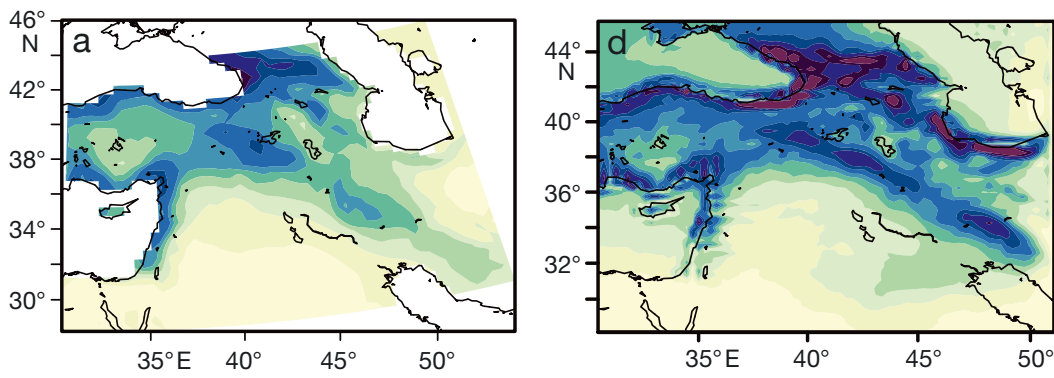

Precipitation
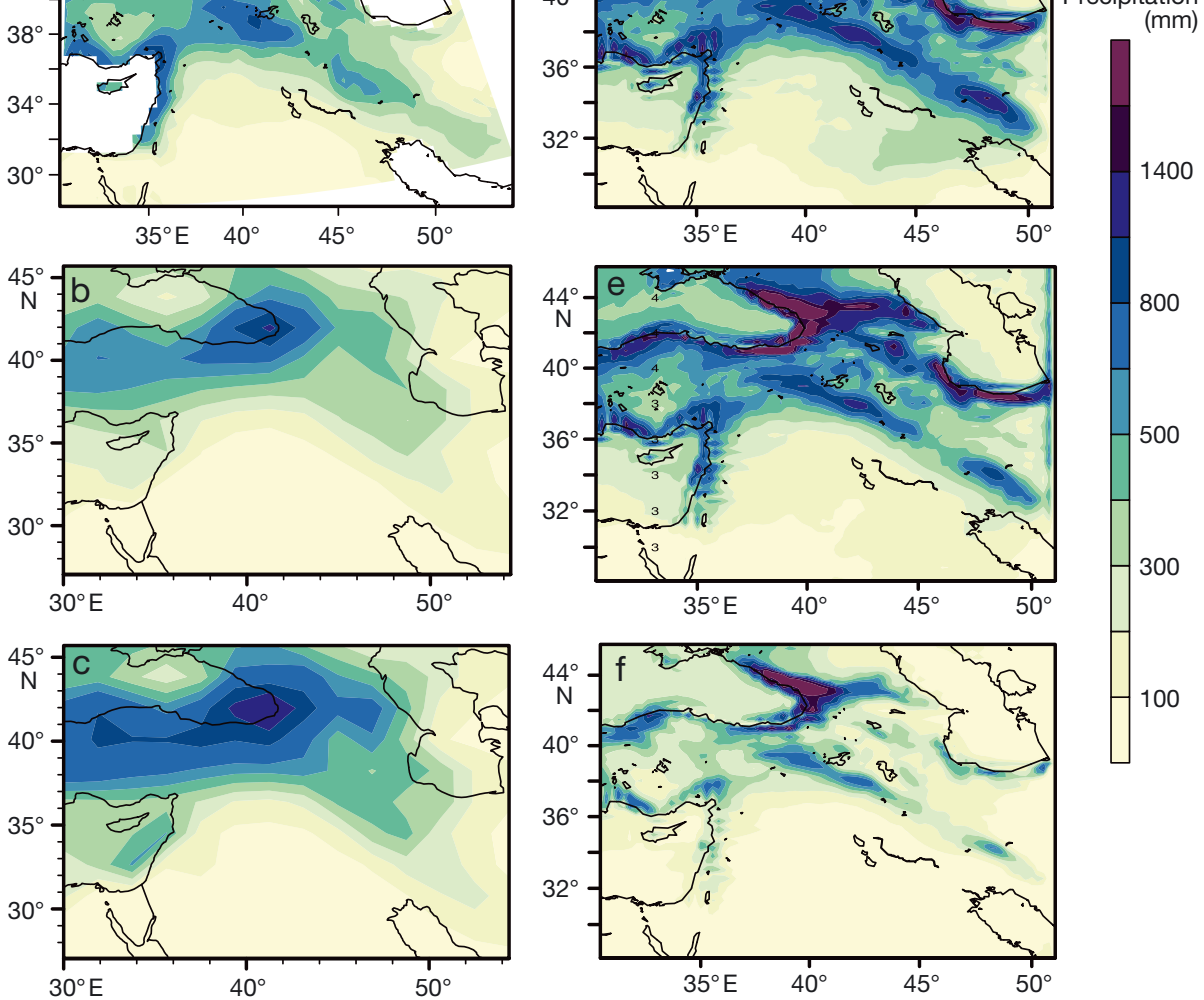

Fig. 3. Thirty-year mean annual precipitation distribution for (a) CRU, (b) GCMECHAM5, (c) MPI-ESM, (d) RCM-NCEP/NCAR, (e) RCM-ECHAM5 and (f) RCM-CCSM3

during the cold season in the RCM-forced simulations is mainly related to the annual precipitation cycle of the RCM simulations. Indeed, compared to the average annual cycle of precipitation at the meteorological stations, the average precipitation in the upper Euphrates Basin from the simulated RCM grid produces an overestimation in the cold season, which is more pronounced for RCM-NCEP/NCAR and RCMECHAM5 (Fig. 5a). One of the remarkable points illustrated in Fig. 2 is that the greatest differences in discharge take place in March and April, when the snowmelt process dominates. In addition to the precipitation overestimation in these months, compared to the CRU-averaged annual cycle of temperature, the simulated RCM grid averaged temperature in the upper Euphrates Basin presents an overestimation during the winter months and early spring (Fig. $5 b)$. Therefore, warmer temperature values in transition months may account for high discharge

months (March-May). Clear differences between CMIP5 and CMIP3 simulations have been illustrated in both the mean annual cycle and the amount of precipitation. Although the dryness in cold season months has been improved in the CMIP5 ensemble, with values closer to those observed, a striking overestimation occurs in the spring months (March-May), which is in contrast to CMIP3 simulations. The simulated precipitation by MPI-ESM is more or less consistent with that of the CMIP5 ensemble.

A comparison of the grid-averaged annual precipitation cycle of MPI-ESM and GCM-ECHAM5 to that of the meteorological stations averaged in the upper Euphrates Basin, which is the main headwater for the basin (see Fig. 1), yields a poor match in the spring season for the GCM-ECHAM5 (Fig. 5a). This poor matching may account for the low peak season discharge in the HD model simulations forced by GCMECHAM5 output (see Figs. 2 \& 4a). It should also be noted that high and rough topography may be the primary reason for the poor match between the coarse grid box precipitation and the meteorological stations. On the other hand, the overestimation of discharge values in RCM-forced simulations. In summary, the HD model seems to simulate the discharge in the ETB reasonably well, as deviations in simulated discharge from observations can be attributed primarily to biases and deficiencies in the input from the respective climate models.

\section{PROJECTED RIVER DISCHARGE}

\subsection{GCM-forced simulations}

Fig. 6 shows the spatially distributed discharge of the GCM-driven simulations on the HD model river network for the reference and future periods. In general, both GCM-forced simulations indicate a striking decrease in discharge from the Euphrates and Tigris Rivers. The MPI-ESM-forced simulations yield more decrease in discharge. Mean annual discharge is projected to decrease by $15-20 \%$ in the upper parts of the basin and the main routing paths of the Euphrates and Tigris Rivers for the GCM-ECHAM5-forced simulations, while it is projected to decrease by $20-25 \%$ 

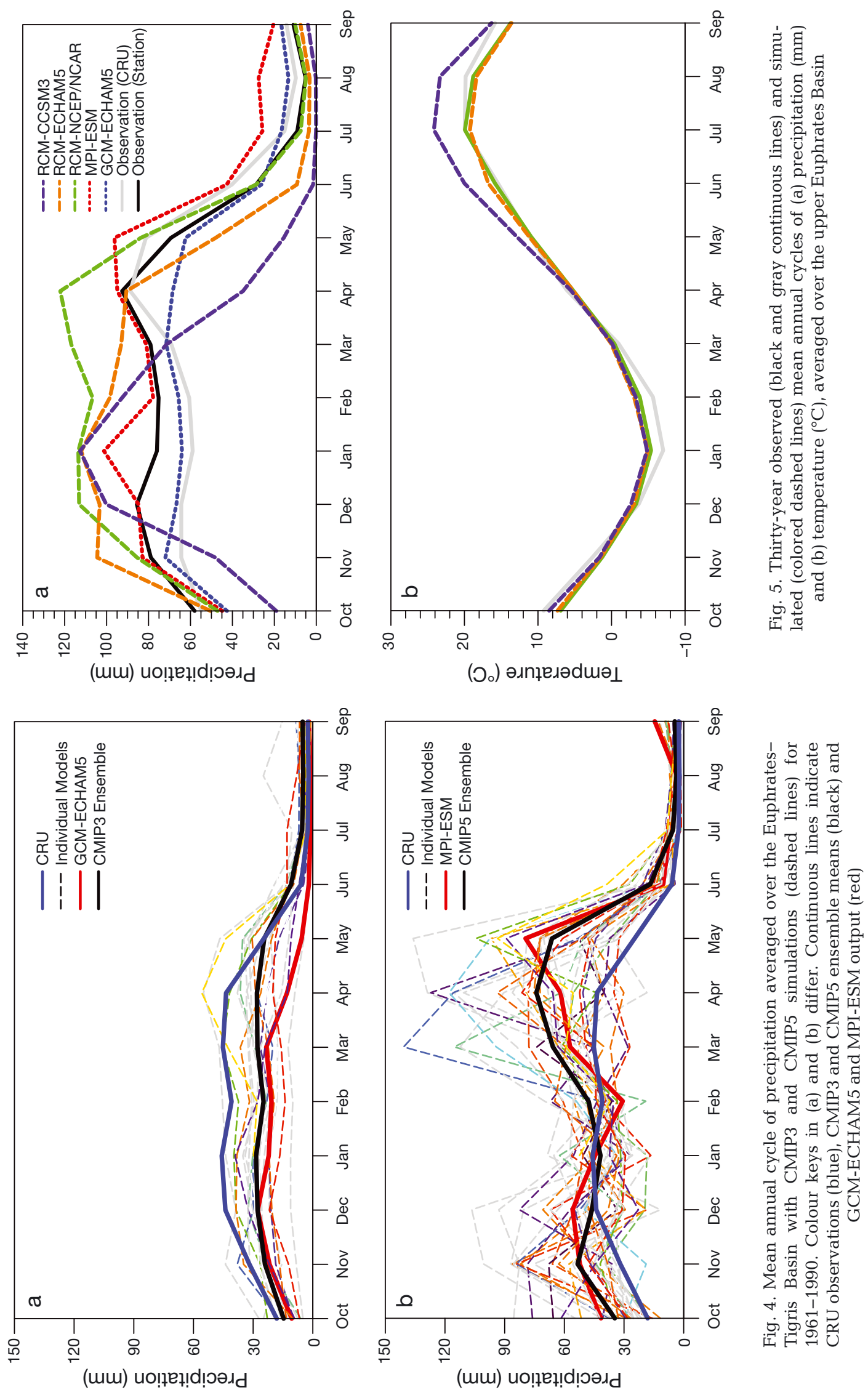
for the MPI-ESM-forced simulations. It should also be noted that the GCM-ECHAM5-forced simulations indicate a slight increase in discharge over the southeastern parts of the basin by the end of the century under the A1B emission scenario. Differences in the input fields of the GCM-ECHAM5 and MPI-ESM may be accounted for by differences in the behavior of the projected discharge. Indeed, future and reference period differences in raw total runoff outputs of the GCM-ECHAM5 and MPI-ESM indicate substantial differences in the southeastern parts of the basin (not shown here). Raw GCM-ECHAM5 differences indicate an increase in total runoff for this region.

Fig. 7 depicts the mean annual discharge cycle of the reference and future periods at the Palu, Bağıştaş and Hindiya stations from GCM-ECHAM5- and MPIESM-forced simulations. In ECHAM5-forced simula-
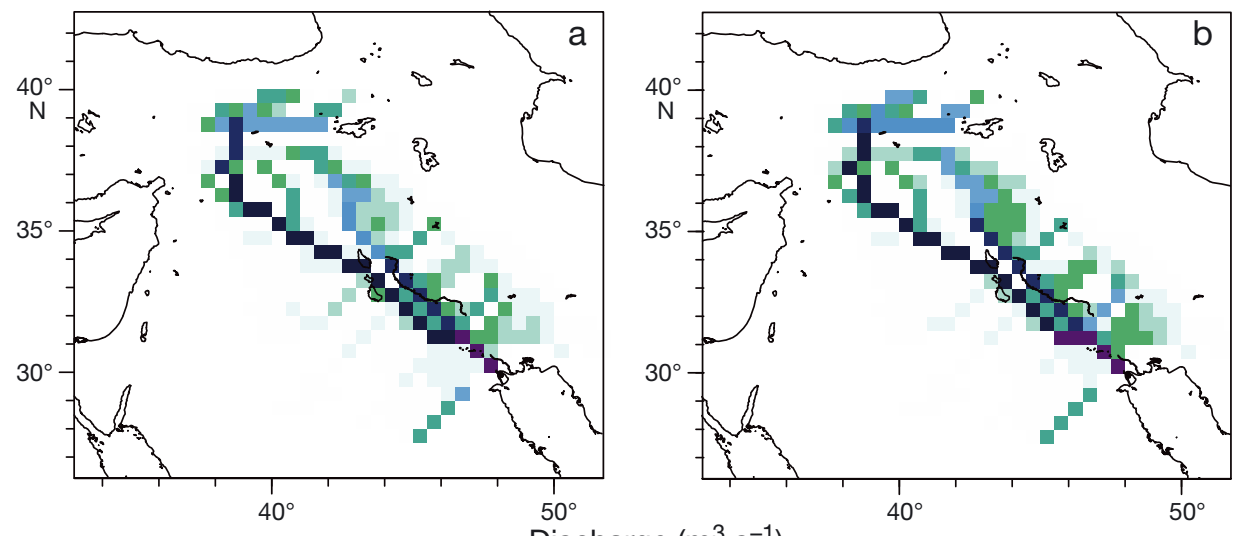

Discharge $\left(\mathrm{m}^{3} \mathrm{~s}^{-1}\right)$
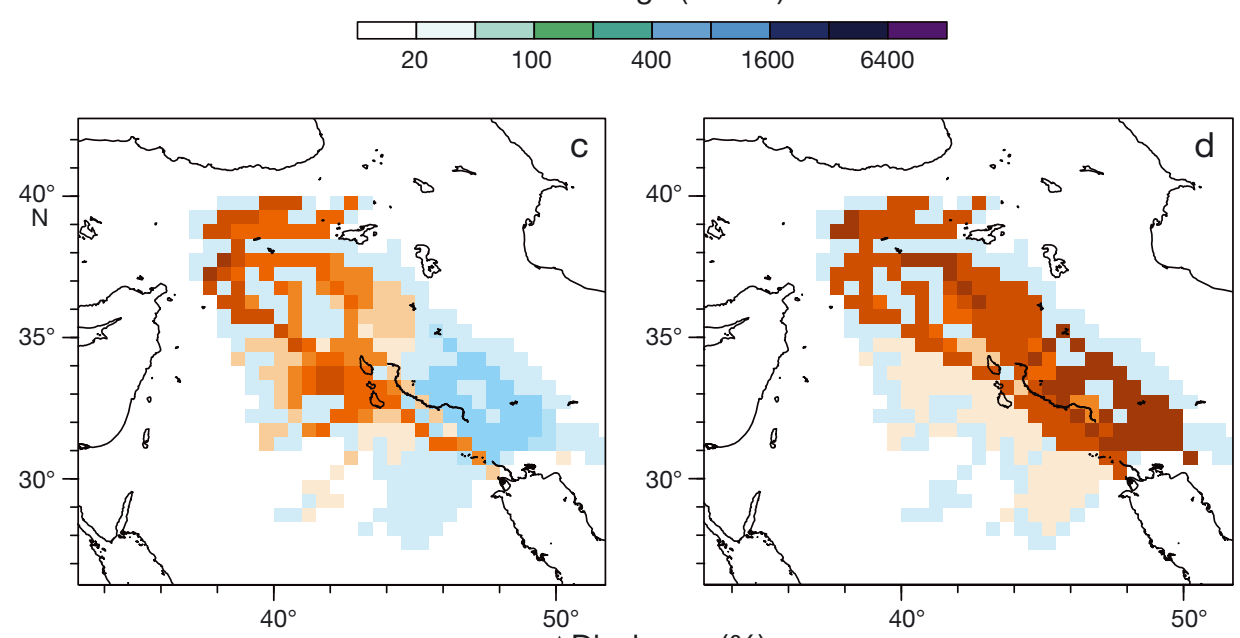

$\Delta$ Discharge $(\%)$

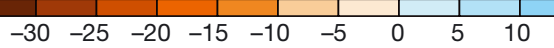

Fig. 6. (a,b) Thirty-year reference period HD model simulations of mean annual discharge for (a) GCM-ECHAM5 (1961-1990) and (b) MPI-ESM (1971-2000). (c,d) Thirtyyear mean annual discharge differences from the reference period: future projections (2071-2100) of (c) GCM-ECHAM5 and (d) MPI-ESM are based on SRES A1B and RCP 4.5 scenarios, respectively tions, the discharge is projected to increase slightly between the months of November and January; however, it is expected to decrease during the rest of the year. Overall, total discharge is projected to decrease for these stations by the end of the century. As the increase in temperature is more pronounced at the end of the century, which means earlier melting of snow, the slight increase in discharge between November and January is related primarily to the temporal shifts in snowmelt runoff. As for the GCMECHAM5-forced simulations, total discharge is projected to decrease in MPI-ESM-forced simulations by the end of the century. Here, this decrease is expected to occur throughout the whole year, and to be most pronounced in the spring months.

In addition to changes in the projected annual cycle, it is important to consider changes in the timing of peak discharge during the water year (October 1 to September 30). Fig. 8 shows the reference term and projected fractions of accumulated discharge for the Palu, Bağıştaş and Hindiya stations. Vertical arrows correspond to the days when $50 \%$ of annual discharge is reached, which is analogous to the 'center time' (CT) concept, which defines the date that marks the timing of the center of mass of annual flow (Stewart et al. 2005). The CT of the reference period is noted as the second half of March for the GCM-ECHAM5-forced simulations, and as the beginning of April for the MPI-ESMforced simulations. Projected daily discharge indicates a shift in the CT towards earlier days in the year at each station; this is more pronounced for the GCM-ECHAM5-forced simulations.

\subsection{RCM-forced simulations}

Fig. 9 shows the HD model results of mean annual discharge and CT changes forced with the RCM-ECHAM5 A2 scenario simulation. As the dy- 

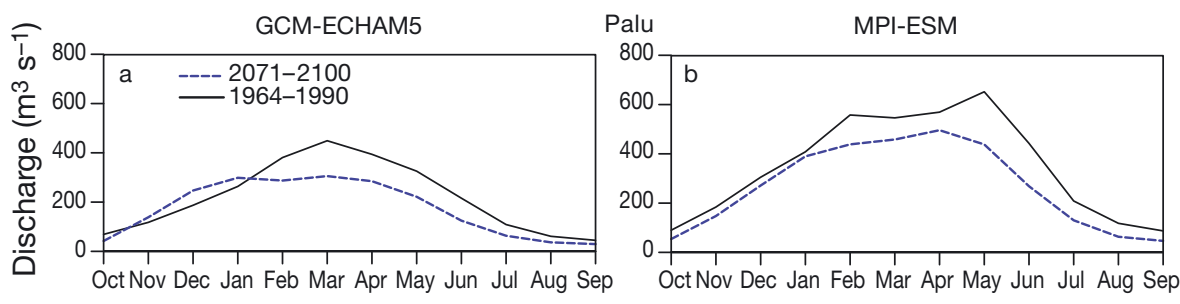

The decrease in projected river discharge and considerable shifts in CT to earlier dates are consistent with snow water equivalent (SWE) changes. As most of the water resources of the basin are fed by snowmelt runoff from the snow-

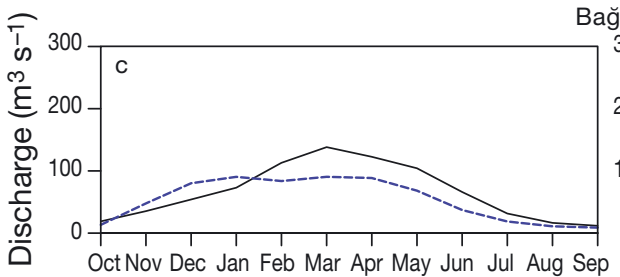
Bağıştaş
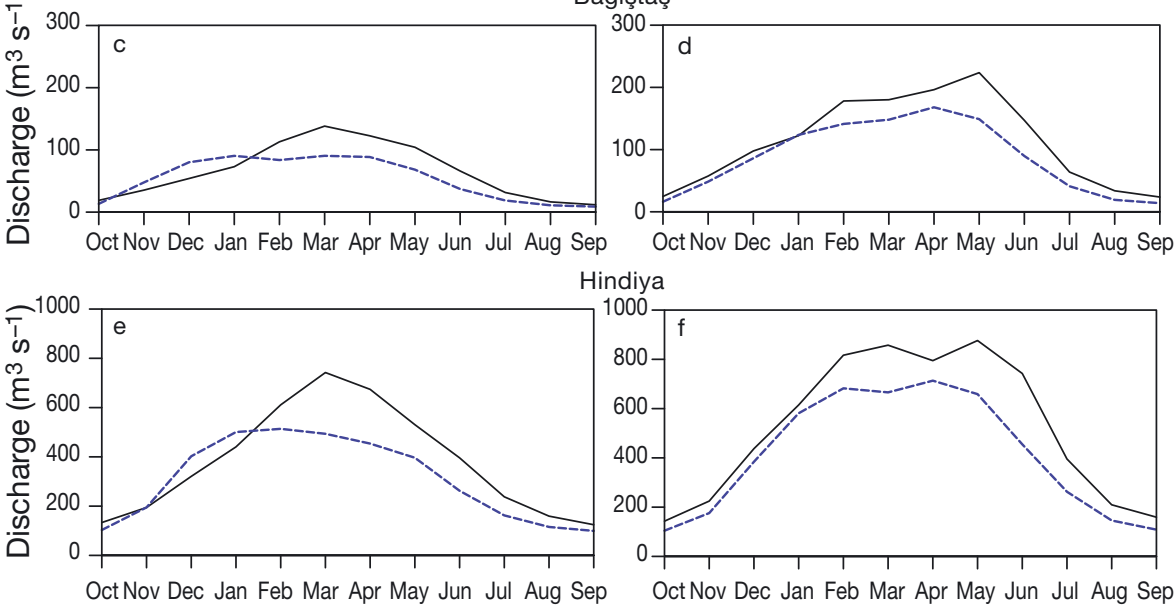

Hindiya

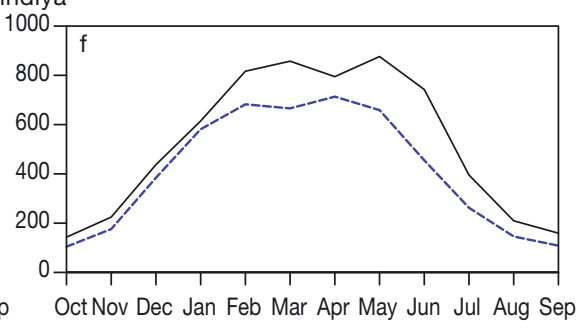

Fig. 7. Mean monthly discharge $\left(\mathrm{m}^{3} \mathrm{~s}^{-1}\right)$ simulated by the HD model for $(\mathrm{a}, \mathrm{b})$ Palu, $(c, d)$ Bağıştaş and $(e, f)$ Hindiya for the reference (black solid line) and future (blue dashed line) periods. Forcing - $(\mathrm{a}, \mathrm{c}, \mathrm{e}) \mathrm{GCM}-\mathrm{ECHAM}$; $(\mathrm{b}, \mathrm{d}, \mathrm{f})$ MPI-ESM capped eastern Taurus and Zagros mountains, snowmelt plays a key role in the regional hydrological cycle. Fig. 13 demonstrates the projected relative changes $(\%)$ in the winter SWE of RCM-ECHAM5 and RCM-CCSM3 simulations. By the end of the century, according to the A2 scenario simulations, relative decreases in SWE in the highlands of the ETB will range, in general, from 70 to $90 \%$. The CCSM3 simulation following the B1 scenario indicates $30-50 \%$ decreases in SWE in mountainous regions. The relative changes at higher elevations are generally more restricted than those at lower elevations, and the altitudinal gra-

namically downscaled simulations cover the mid-century as well, 2 periods are considered: 2040-2069 and 2070-2099. In the mid-century, it is projected that there will be a slight decrease in discharge for the 3 stations. However, there is no striking change in the CT date of the discharges. By the end of the century, however, all stations are expected to have less discharge and considerable shifts to earlier dates.

Figs. 10-12 show the HD model results forced with the RCM-CCSM3 A1FI, A2 and B1 scenarios, respectively. It is clear that discharge is projected to decrease dramatically by mid-century and the end of the century under both the A1FI and A2 scenarios. Moreover, noticeable shifts in discharge to earlier dates are projected under the A1FI and A2 scenarios. On the other hand, relatively small reductions in discharge and shifts are projected under the B1 scenario, which has lower emissions. Table 3 provides the CT dates for both reference and future periods, as well as changes in mean annual discharge from the RCM-forced simulations. The discharge CT occurs in early April for the reference period, and is projected to shift to 3-5 wk earlier (to early and mid-March) for future periods. All simulations indicate significant decreases in discharge by the end of century, ranging from $19-58 \%$ depending on the model and emission scenario. dient of the SWE response to climate change will likely result in the disappearance of snow cover at lower elevations $(<1000 \mathrm{~m})$. Similar results have been highlighted in previous studies as well (e.g. Özdoğan 2011, Bozkurt \& Sen 2013, Önol et al. 2014).

\section{SUMMARY AND CONCLUDING REMARKS}

In a comprehensive 1-way coupling study of the (ETB), we forced the Max Planck Institute for Meteorology's hydrological discharge model with a variety of modeled datasets to investigate the future of discharge in the basin. The data include daily time series of surface runoff and sub-surface runoff outputs of 2 GCMs, the SRES A1B scenario output of ECHAM5/MPIOM and the RCP 4.5 scenario output of MPI-ESM-LR, and the dynamically downscaled output of ECHAM5/MPIOM and NCAR-CCSM3 based on the SRES A1FI, A2 and B1 scenarios obtained by ICTP-RegCM3. The objective of the present study was, therefore, 2-fold: (1) to present and evaluate the performance of the HD model in the basin, and (2) to demonstrate the projected river discharge for the basin, which is considered waterstressed in a region that is strongly influenced by water-scarcity events. Furthermore, the GCM-forced 


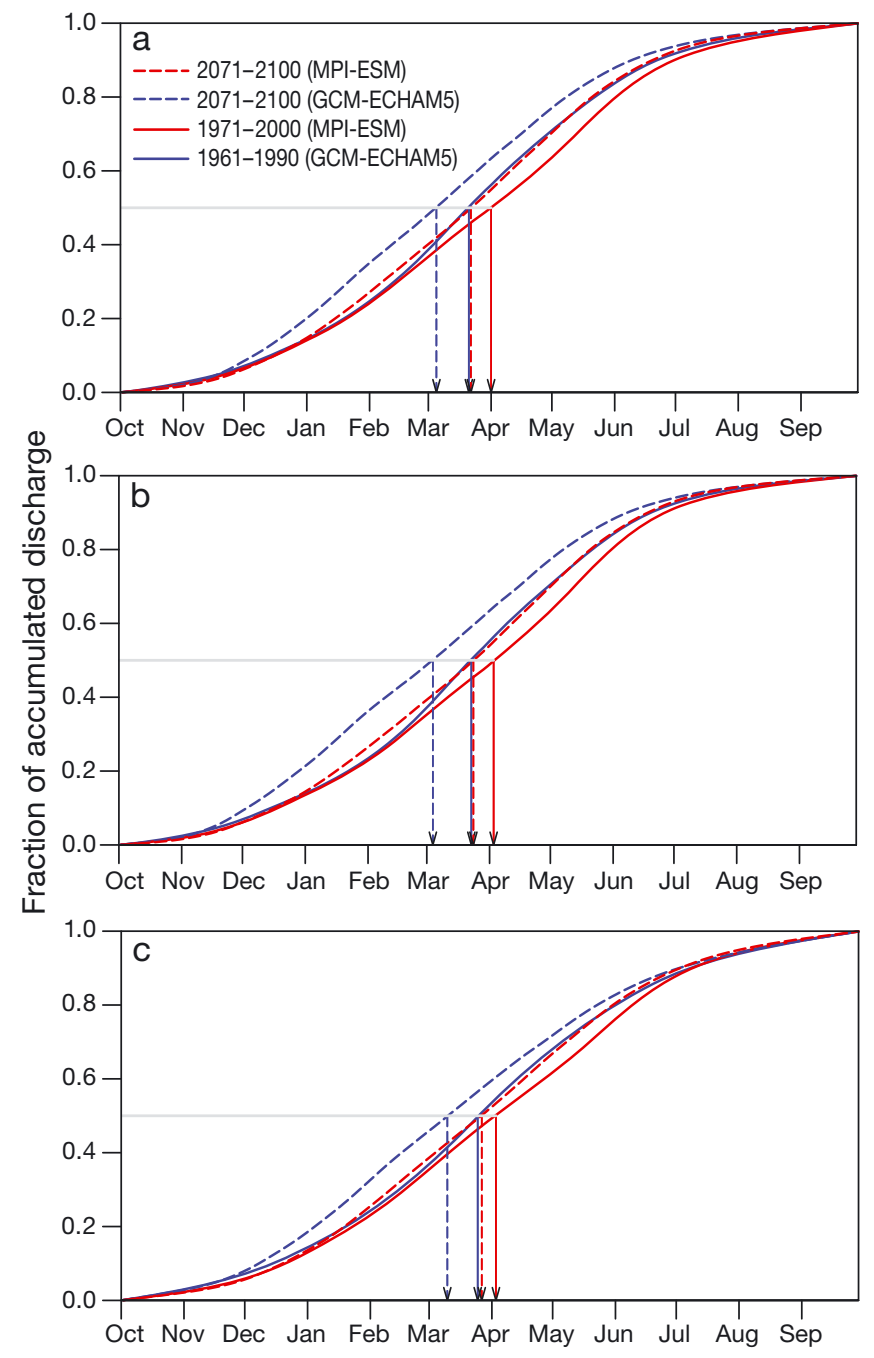

Fig. 8. Fraction of accumulated discharge for the reference period (continuous line) and future period (dashed lines) from the GCM-ECHAM5-forced (blue) and MPI-ESMforced (red) simulations for the (a) Palu, (b) Bağıştaş and (c) Hindiya stations. Vertical arrows: days when $50 \%$ of annual discharge is reached

simulation results provide a comparison of the CMIP5 simulations with MPI-ESM and the CMIP3 results with its predecessor the GCM-ECHAM5 over the ETB. In this respect, the present study was also able to capitalize on information from another, very recent study by Hagemann et al. (2013a), who compared MPI-ESM with its predecessor GCMECHAM5 in terms of land surface water and energy fluxes. Detailed information on the dynamically downscaled reference period simulations and their evaluation with respect to the observations can be found in Bozkurt et al. (2012). HD simulations have been carried out by using surface runoff and subsurface runoff from the GCM and RCM outputs.
In terms of evaluation of the HD model, it has been demonstrated that the simulations forced with lowresolution GCM outputs cannot reproduce the seasonal cycle of discharge very well. Moreover, the simulations do not capture the timing of the annual peak discharge. These failures are mostly related to the shortcomings of the GCM fields. Since surface orography is a major factor in the precipitation distribution over the basin highlands, the coarse resolution of the GCMs does not seem to be adequate to represent the spatial distribution of precipitation. It should also be noted that the simulations forced with the MPI-ESM yield better results than the GCM-ECHAM5-forced simulations. In this regard, a very recent study by Hagemann et al. (2013a) has provided some insight by comparing the MPI-ESM with its predecessor GCM-ECHAM5 in terms of land surface water and energy fluxes. Hagemann and coworkers noted that the MPI-ESM simulation of precipitation is improved over central and southern Europe, as well as over the Middle East, during the boreal summer. During the boreal winter, MPI-ESM tends to overestimate the precipitation of the ETB, while GCM-ECHAM5 underestimates precipitation. A comparison of GCMECHAM5 and MPI-ESM relative to the CMIP3 and CMIP5 ensemble means in the basin indicates that GCM-ECHAM5 simulation produces drier conditions compared to the CMIP3 ensemble, which is more pronounced in spring months (March-May). On the other hand, the simulated precipitation by MPI-ESM is more or less consistent with that of the CMIP5 ensemble.

In contrast to GCM-forced simulations, high-resolution RCM-forced simulations reproduce the annual cycle of discharge reasonably well. However, overestimation of the discharge during the cold season and a bias in the timing of the springtime snowmelt peak of discharge persist in the RCM-NCEP/NCAR- and RCM-ECHAM5-forced simulations. Overestimation of discharge may be attributed to some shortcomings in the simulated RCM precipitation, especially in connection with the annual cycle of precipitation. Indeed, a comparison of the RCM-simulated and observed annual cycle of precipitation indicates an overestimation of precipitation in the cold season over the upper Euphrates Basin. Furthermore, warmer temperature values in the transition month (March) may account for the peak discharge values being too high in the RCM-driven simulations.

Future river discharge simulations indicate a striking decrease in mean annual discharge from the Euphrates and Tigris Rivers by the end of the century, ranging from 19 to $58 \%$ based on RCM-forced 

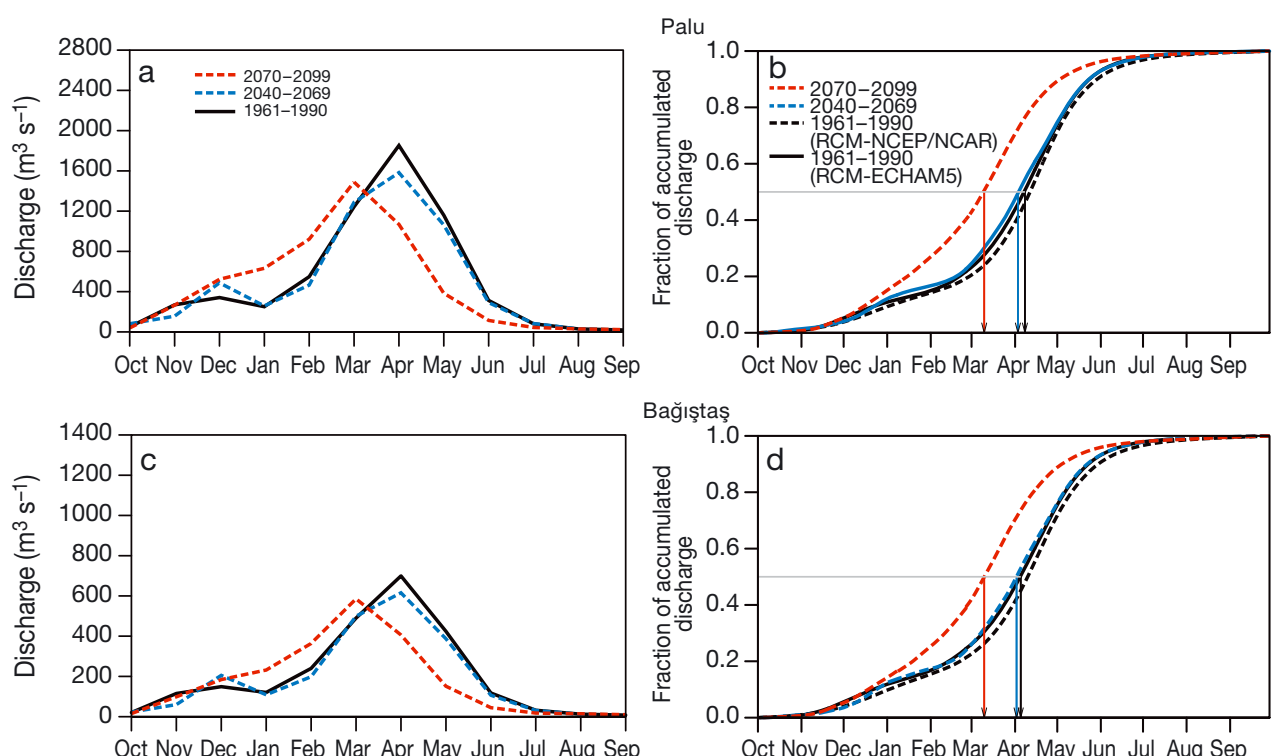

Bağıştaş
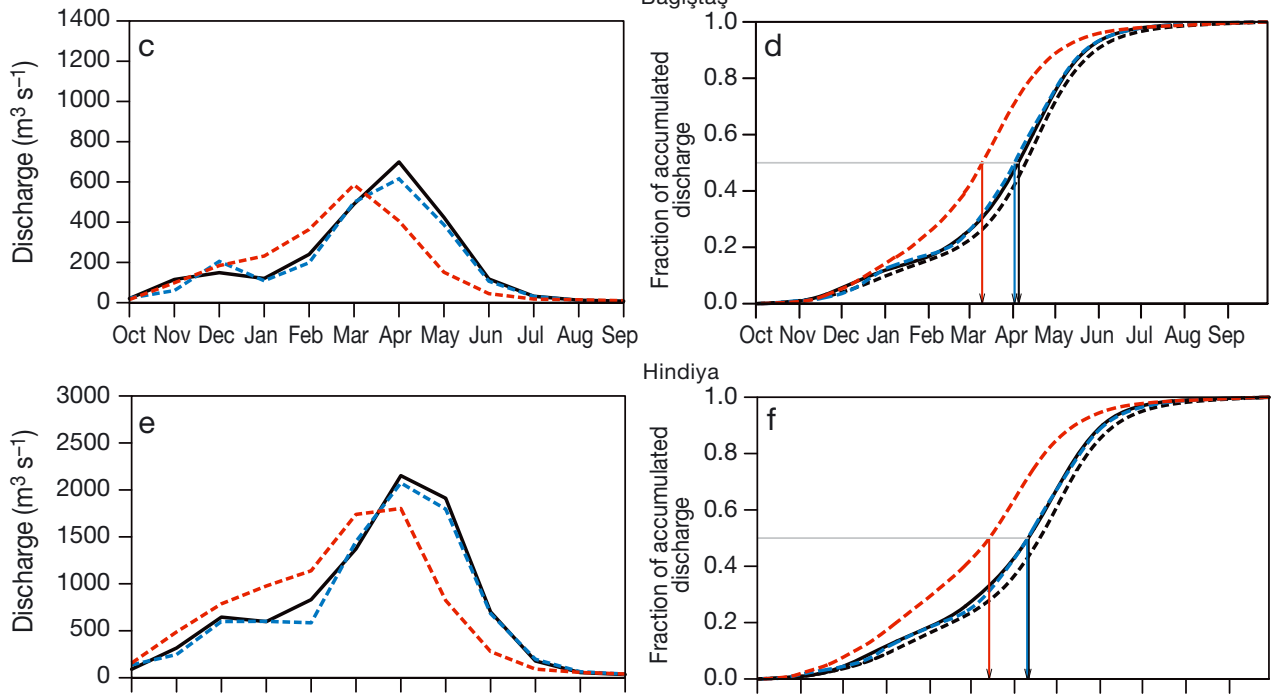

Oct Nov Dec Jan Feb Mar Apr May Jun Jul Aug Sep Hindiya
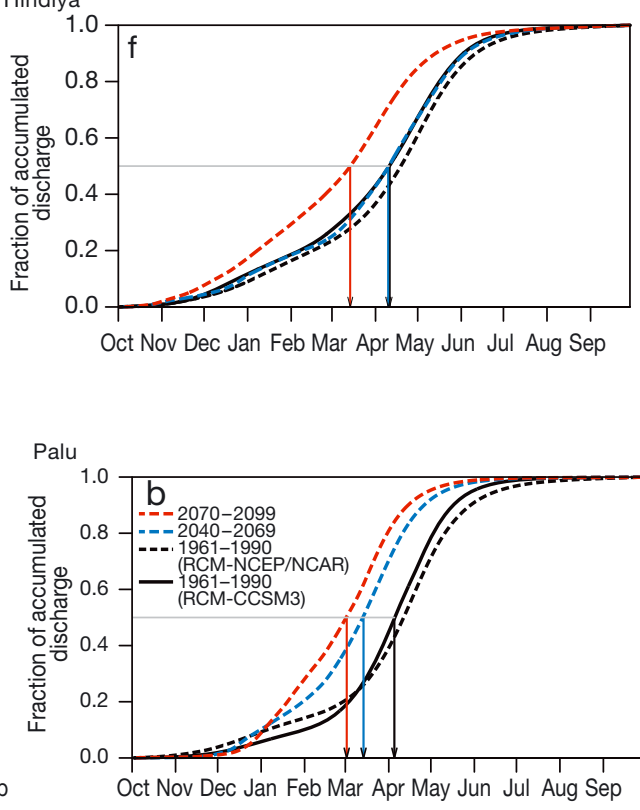

Bağıştaş
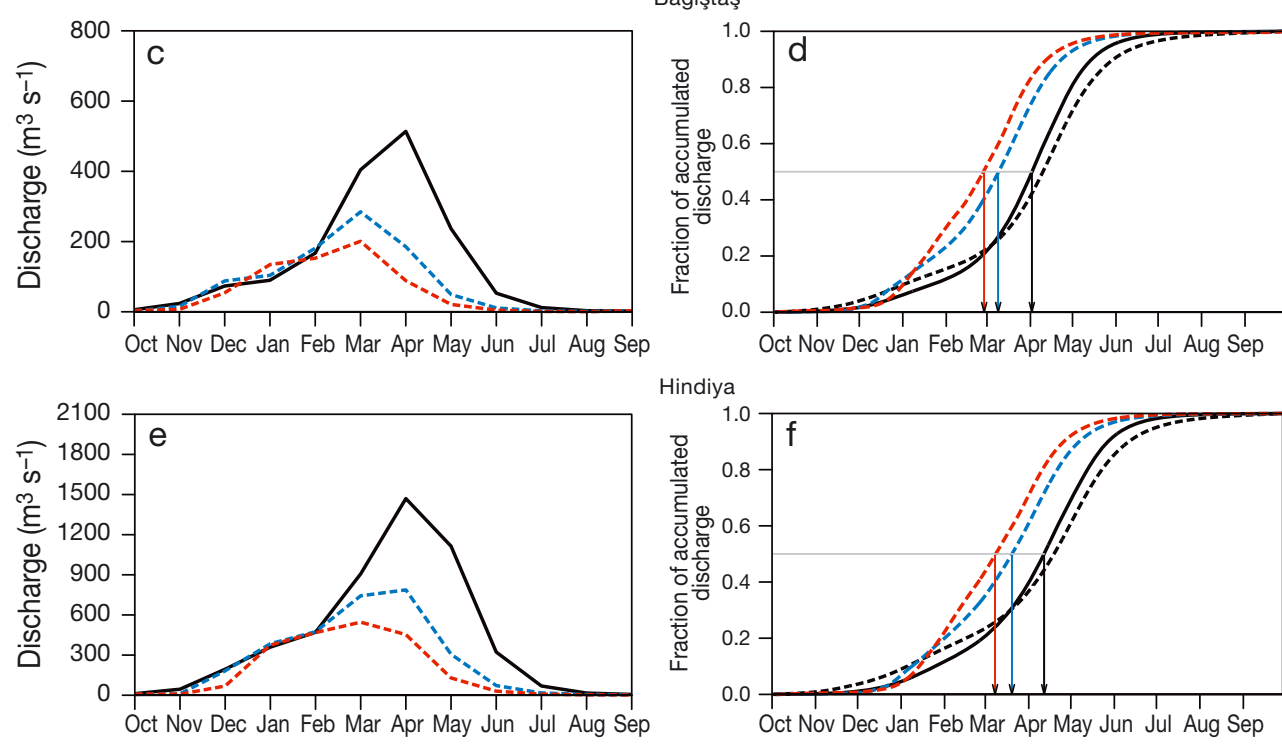

Hindiya

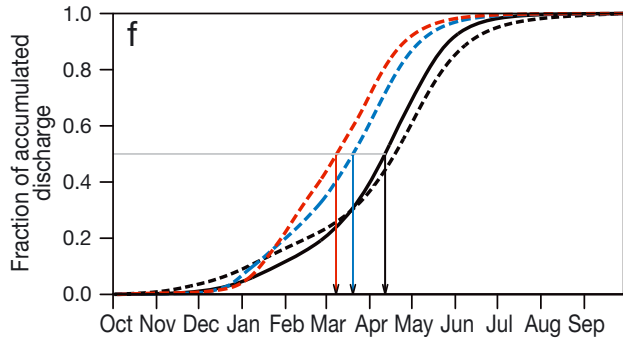

Fig. 9. HD model simulations of discharge for the reference (black) and future periods (blue for mid-century, red for end of the century) forced with the RCMECHAM5 A2 scenario. (a,b) Palu; (c,d) Bağıştaş, (e,f) Hindiya. Left column: mean monthly discharge $\left(\mathrm{m}^{3} \mathrm{~s}^{-1}\right)$; right column: the fraction of accumulated discharge. Vertical arrows: days when $50 \%$ of annual discharge is reached
Fig. 10. Same as for Fig. 9, but for the RCM-CCSM3 A1FI scenario 
Fig. 11. Same as for Fig. 9, but for the RCM-CCSM3 A2 scenario
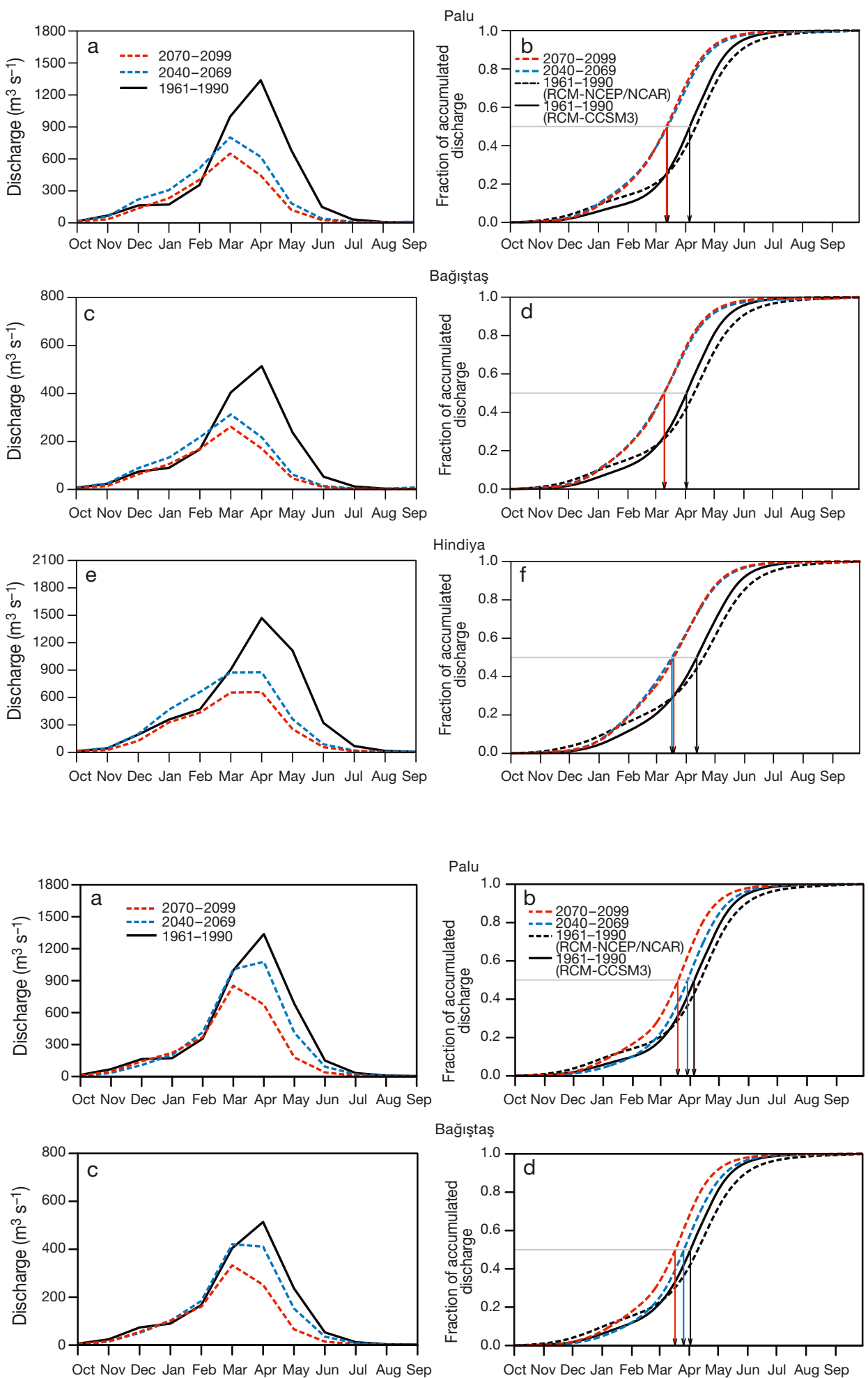

Bağıştaş

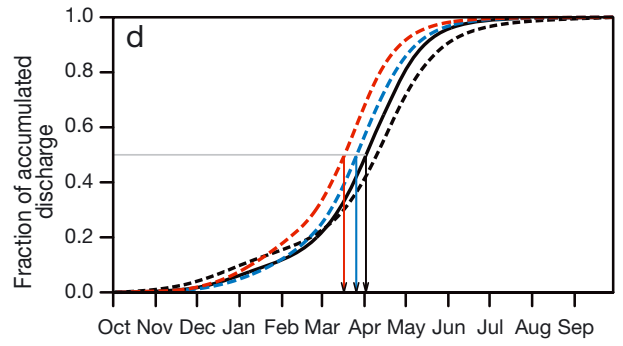

Hindiya
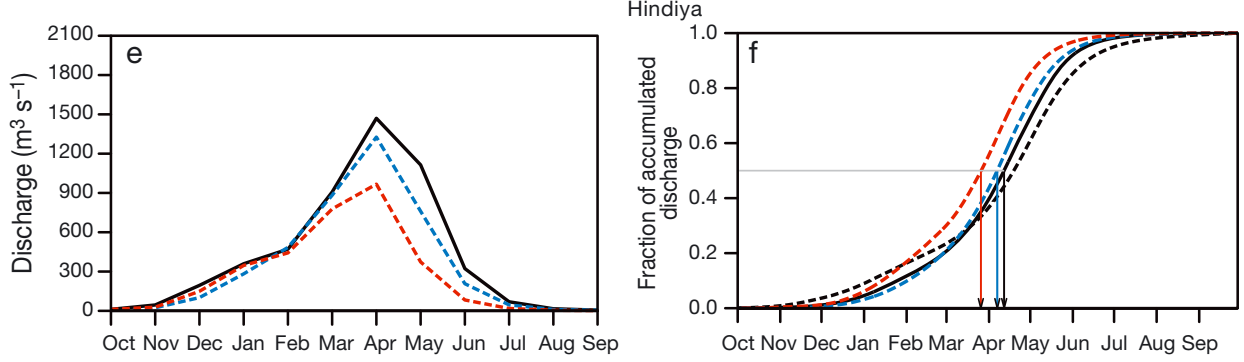

Fig. 12. Same as for Fig. 9, but for the RCM-CCSM3 B1 scenario 
Table 3. Central time (CT) dates for both reference and future periods, and changes in mean annual discharges from the RCM-forced simulations

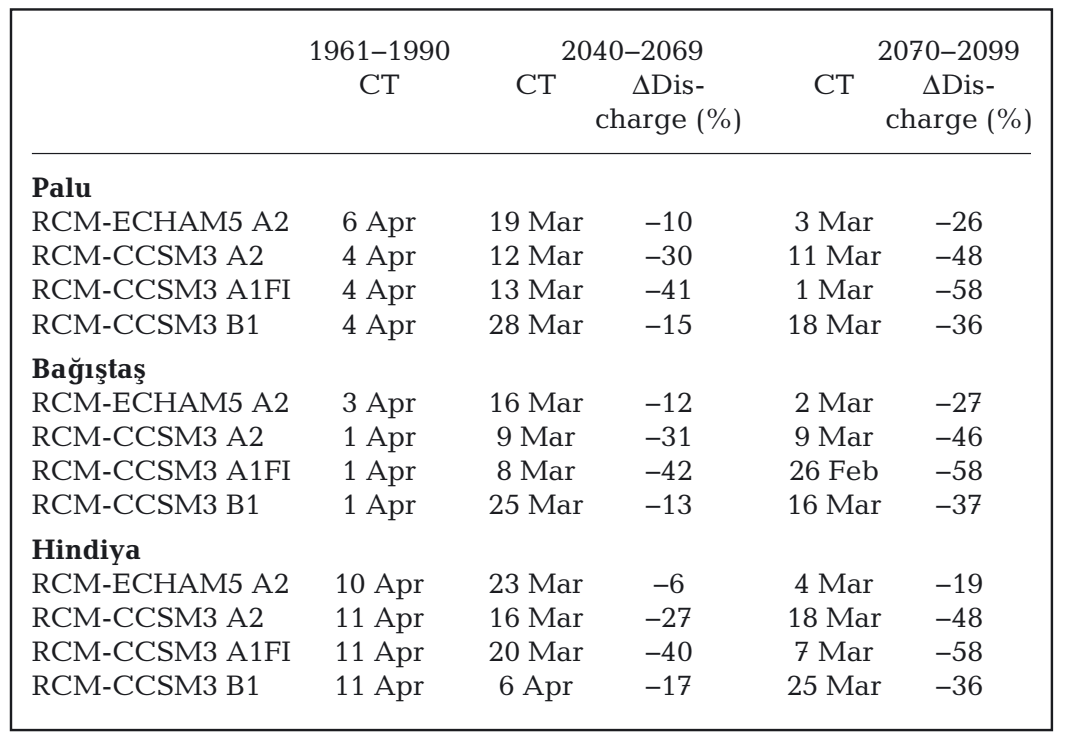

simulations and emission scenarios. In addition, significant temporal shifts in the discharge center time of 3-5 wk earlier are projected to occur by the end of the century. Different model and scenario combinations are in agreement with these 2 main results, which are related primarily to a substantial decrease in the SWE in the basin highlands. A study by Önol et al. (2014), which also analyzed climate change projections for the Anatolian highlands, reports that SWE in winter will decrease dramatically at middle (between 1500 and $2000 \mathrm{~m}$ ) and higher (over $2000 \mathrm{~m}$ ) elevations after the mid-21st century.

Projections of future climate change may comprise substantial uncertainties introduced by the GCMs, the
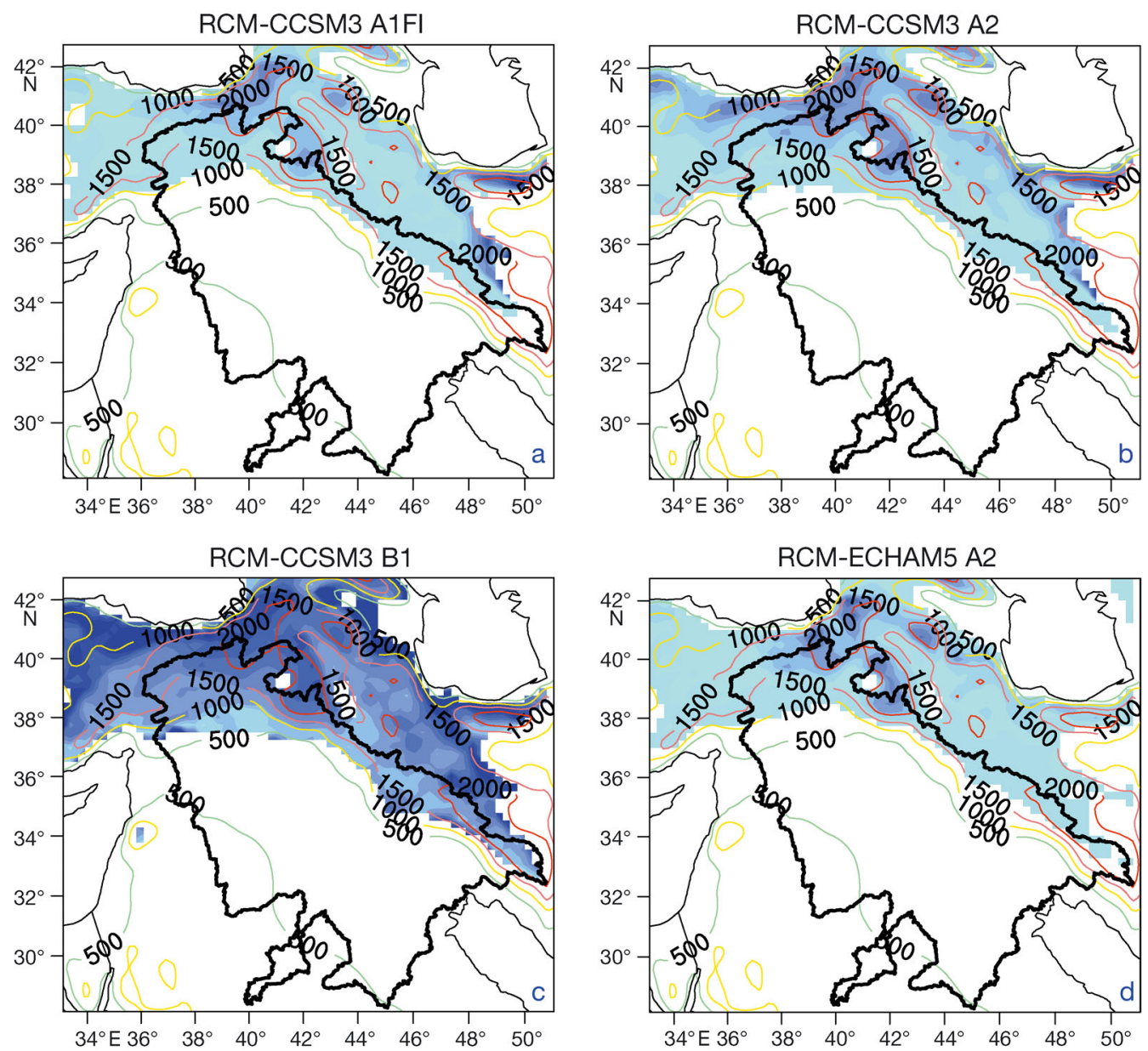

Fig. 13. Dynamically downscaled winter snow water equivalent changes (background color pattern; in percent) by the end of the century (20712099) relative to the 1961-1990 reference period for $(\mathrm{a}-\mathrm{C})$ the CCSM3 A1FI \& A2 \& B1 scenarios, respectiely, and (d) the ECHAM5 A2 scenario. $\Delta$ Snow water equivalent (\%) Elevations indicated by contour lines $(\mathrm{m})$ 
scenarios, the RCMs, etc. If we put the scenario uncertainty aside, it could be said that the major source of uncertainty is the GCM itself. In downscaling studies, the RCMs propagate these uncertainties to the high-resolution outputs. The RCMs themselves may introduce further uncertainty to the outputs. Thus, this chain of uncertainty may affect climate change impact studies, especially those that are done using RCM output. Hemming et al. (2010) found larger ranges in the uncertainty of projected precipitation from RCM compared to GCM ensemble members over the Middle Eastern region, which indicates that increasing the model resolution might lead to increases in the sensitivity of the simulated precipitation. Another source of uncertainty comes from terrestrial processes related to land cover, as land cover change is not considered in most of the GCM- and RCM-based climate change projections. In this study, land cover change was not considered in either the GCM-ECHAM5 or the RCM, but MPI-ESM does take land cover change into account as described in Reick et al. (2013). Moreover, some other general model uncertainties with regard to parameterizations and missing processes (e.g. convective scheme, dust and aerosol module, soil moisture) may also contribute to the RCM-propagated uncertainties. Different approaches are adopted to eliminate, at least partially, the uncertainties caused by the models themselves. The most common approach is to work with the changes instead of with absolute values, which is the method we adopted in our study, and we, therefore, emphasize the changes rather than the absolute values. In studies that involve the forcing or coupling of full hydrology models, i.e. where the land surface water fluxes are completely calculated by the hydrology model forced by atmospheric states and fluxes of a climate model, bias correction methods are commonly used. But, there are some recent studies that indicate there are problems in using such methods for climate change impact studies. Hagemann et al. (2011) pointed out that the usage of bias-corrected GCM data leads to an improved simulation of river runoff for most catchments in the world. However, they also found that bias correction has an impact on the climate change signal for specific locations and months. Moreover, they concluded that 'it is rather difficult to judge whether the impact of the bias correction on the climate change signal leads to a more realistic signal or not' (p. 576). Muerth et al. (2012) investigated the need for bias correction in regional climate scenarios in order to assess the climate change impacts on river runoff. They tried to address the question 'Is it really necessary to correct biases to assess climate change impacts, if uncorrected RCM data does not reproduce observed conditions very well?' in their study. They noted that bias correction of climate model outputs is important in terms of the reproduction of runoff. However, the impact of bias correction on the relative change of flow indicators between reference and future periods is mostly weak in this study. Finally, Ehret et al. (2012) presented a brief overview of state-of-the-art bias correction methods used in climate change impact studies. They concluded that the current bias correction method used for correction of GCM/RCM model output in climate change impact studies is not a valid procedure, since it impairs the physical coherence between atmospheric and land-surface variables in circulation models. In order to ensure consistency between the climate model data and the simulated discharge for both present and future climates, we restrained from using bias correction. In addition, a bias correction for precipitation (which is mainly responsible for overestimated discharge) would require use of a full hydrology model that calculates all surface-water fluxes (evapotranspiration, runoff) newly without any feedback to the atmosphere, so that these fluxes will also not be consistent to the atmospheric climate model fields. While this is justified for dedicated applications, we have chosen in our study to place a higher value on the consistency of variables than on the correction of model bias. A comparative study of the ETB testing these 2 approaches is desirable for the future.

The results of this study together with those of several recent publications (e.g. Özdoğan 2011, Bozkurt \& Sen 2013, Önol et al. 2014) have important implications for the future of the ETB, a multi-national basin in the Middle East. It is becoming clearer that climate change will not only decrease the water supply, but also change river flow regimes in the basin. There is no doubt that these changes will affect human activities in the area, including hydropower energy production and agricultural irrigation, as well as the unique ecosystems along the rivers and the vast marshes of Iraq. Many dams with hydropower plants are located in the basin, especially in the upstream part. The projected reductions in river discharge will decrease the hydropower potential of the basin and, hence, adversely affect the production of electricity. The aggressive irrigation projects that have been pursued in recent years, with the transfer of water from the reservoirs behind these dams to the vast plains of Mesopotamia, have resulted in a significant extension of the agricultural fields in the basin. However, the cost of this development is enhanced water 
loss through evapotranspiration. As regional development projects foresee further expansion of irrigated agricultural fields, it is to be expected that water loss through evapotranspiration will continue to increase in the future. This means that climate change will not only exacerbate the reduction in discharge but also water loss area due to additional evaporative surface area. Thus, increased pressure on the shrinking water resources may lead to further disputes in the region. These prospects should be taken into account in the development of future climate change mitigation and water management strategies for the ETB.

Acknowledgements. This study was partially supported by a grant (109Y287) from the Scientific and Technological Research Council of Turkey (TUBITAK). Hydrological discharge simulations were carried out during a stay at the Max Planck Institute for Meteorology (MPI-M) in Hamburg, Germany, under a $\mathrm{PhD}$ research scholarship provided by TUBITAK. The first author acknowledges TUBITAK and the MPI-M for their support. The first author also acknowledges FONDAP/CONICYT Chile (Grant 15110009-CR2) for a post-doctoral fellowship that helped to finalize the study. The study was also made possible through funding from the United Nations Development Programme (UNDP) within the framework of the 'MDG-F 1680' project entitled 'Enhancing the Capacity of Turkey to Adapt to Climate Change'. We are thankful to the project team that generated the climate change projections and made them available. Regional climate model simulations were performed at the National Center for High Performance Computing at the Istanbul Technical University. We thank 3 anonymous reviewers for constructive comments.

\section{LITERATURE CITED}

Alpert P, Neumann J (1989) An ancient correlation between streamflow and distant rainfall in the Near East. J Near East Stud 48:313-314

Bozkurt D, Sen OL (2013) Climate change impacts in the Euphrates-Tigris Basin based on different model and scenario simulations. J Hydrol (Amst) 480:149-161

Bozkurt D, Turuncoglu U, Sen OL, Onol B, Dalfes HN (2012) Downscaled simulations of the ECHAM5, CCSM3 and HadCM3 global models for the eastern MediterraneanBlack Sea region: evaluation of the reference period. Clim Dyn 39:207-225

Brinkman JA (1968) A political history of post-Kassite Babylonia 1158-722 BC. Analecta Orientalia Ville, Pontificium Institutum Biblicum, Rome

> Brovkin V, Raddatz T, Reick CH, Claussen M, Gayler V (2009) Global biogeophysical interactions between forest and climate. Geophys Res Lett 36:L07405, doi:10.1029/ 2009GL037543

Brovkin V, Boysen L, Raddatz T, Gayler V, Loew A, Claussen M (2013) Evaluation of vegetation cover and land-surface albedo in MPI-ESM CMIP5 simulations. J Adv Model Earth Syst 5:48-57

> Chenoweth J, Hadjinicolaou P, Bruggeman A, Lelieveld J and others (2011) Impact of climate change on the water resources of the eastern Mediterranean and Middle East region: modeled 21st century changes and implications. Water Resour Res 47:W06506, doi:10.1029/2010WR010269 Clarke LE, Edmonds JA, Jacoby HD, Pitcher H, Reilly JM, Richels R (2007) Scenarios of greenhouse gas emissions and atmospheric concentrations. Sub-report 2.1a of Synthesis and Assessment Product 2.1. Climate Change Science Program and the Subcommittee on Global Change Research, Washington, DC

Daoudy M (2004) Syria and Turkey in water diplomacy (1962-2003). In: Zereini F, Jaeschke W (eds) Water in the Middle East and in North Africa: resources, protection and management. Springer, Heidelberg, p 319-332

deMenocal PB (2001) Cultural responses to climate change during the late Holocene. Science 292:667-673

Dickinson RE, Henderson-Sellers A, Kennedy PJ (1993) Biosphere-atmosphere transfer scheme (BATS) Version 1 e as coupled to the NCAR community climate model. Technical Note TN-387+STR, National Center for Atmospheric Research, Boulder, CO

> Ehret U, Zehe E, Wulfmeyer V, Warrach-Sagi K, Liebert J (2012) HESS opinions 'Should we apply bias correction to global and regional climate model data?'. Hydrol Earth Sci Discuss 9:5355-5387

Fritsch JM, Chappell CF (1980) Numerical prediction of convectively driven mesoscale pressure systems. 1. Convective parameterization. J Atmos Sci 37:1722-1733

Gleick P (2014) Water, drought, climate change, and conflict in Syria. Weather Climate Soc 6:331-340

Grell G (1993) Prognostic evaluation of assumptions used by cumulus parameterization. Mon Weather Rev 121:764-787

> Hagemann S, Dümenil L (1997) A parametrization of the lateral waterflow for the global scale. Clim Dyn 14:17-31

Hagemann S, Dümenil L (1999) Application of a global discharge model to atmospheric model simulations in the BALTEX region. Nord Hydrol 30:209-230

> Hagemann S, Dümenil Gates L (2001) Validation of the hydrological cycle of ECMWF and NCEP reanalyses using the MPI hydrological discharge model. J Geophys Res 106:1503-1510

> Hagemann S, Jacob D (2007) Gradient in the climate change signal of European discharge predicted by a multi-model ensemble. Clim Change 81(Suppl 1):309-327 (Prudence Spec Issue)

- Hagemann S, Chen C, Haerter JO, Heinke J, Gerten D, Piani C (2011) Impact of a statistical bias correction on the projected hydrological changes obtained from three GCMs and 2 hydrology models. J Hydrometeorol 12: 556-578

- Hagemann S, Loew A, Andersson A (2013a) Combined evaluation of MPI-ESM land surface water and energy fluxes. J Adv Model Earth Syst 5:259-286

Hagemann S, Chen C, Clark DB, Folwell S and others (2013b) Climate change impact on available water resources obtained using multiple global climate and hydrology models. Earth Syst Dyn 4:129-144

Hemming D, Buontempo C, Burke E, Collins M, Kaye N (2010) How uncertain are climate model projections of water availability indicators across the Middle East. Philos Trans a Math Phys Eng Sci 368:5117-5135

Holtslag AAM, DeBruijn EIF, Pan HL (1990) A high resolution air mass transformation model for short range weather forecasting. Mon Weather Rev 118:1561-1575 Hsie EY, Anthes RA, Keyser D (1984) Numerical simulation 
of frontogenesis in a moist atmosphere. J Atmos Sci 41: 2581-2594

IPCC (Intergovernmental Panel on Climate Change) (2013) Climate change 2013: the physical science basis. Contribution of Working Group I to the 5th Assessment Report to the IPCC. Cambridge University Press, Cambridge

Jungclaus JH, Botzet M, Haak H, Keenlyside N and others (2006) Ocean circulation and tropical variability in the coupled model ECHAM5/MPI-OM. J Clim 19:3952-3972

> Jungclaus JH, Fischer N, Haak H, Lohmann K and others (2013) Characteristics of the ocean simulations in Max Planck Institute Ocean Model (MPIOM), the ocean component of the MPI-Earth system model. J Adv Model Earth Syst 5:422-446

Kaniewski D, Paulissen E, Van Campo E, Weiss H, Otto T, Bretschneider J, Van Lerberghe K (2010) Late secondearly first millennium $\mathrm{BC}$ abrupt climate changes in coastal Syria and their possible significance for the history of the eastern Mediterranean. Quat Res 74:207-215

$>$ Kay PA, Johnson DL (1981) Estimation of the TigrisEuphrates streamflow from regional paleoenvironmental proxy data. Clim Change 3:251-263

Kiehl JT, Hack JJ, Bonan GB, Boville BA, Briegleb BP, Williamson DL, Rasch PJ (1996) Description of the NCAR community climate model (CCM3). NCAR Technical Note, NCAR/TN-420+STR, National Center for Atmospheric Research, Boulder, CO

Kitoh A, Yatagai A, Alpert P (2008) First super-high-resolution model projection that the ancient 'Fertile Crescent' will disappear in this century. Hydrol Res Lett 2:1-4

Lehner B, Verdin K, Jarvis A (2008) New global hydrography derived from spaceborne elevation data. Eos Trans AGU 89:93-94

Meehl GA, Covey C, Delworth T, Latif M and others (2007) The WCRP CMIP3 multimodel dataset: a new era in climate change research. Bull Am Meteorol Soc 88: 1383-1394

- Moss RH, Edmonds JA,Hibbard KA,Manning MR and others (2010) The next generation of scenarios for climate change research and assessment. Nature 463:747-756

Muerth MJ, St-Denis BG, Ricard S, Velazquez JA and others (2012) On the need for bias correction in regional climate scenarios to assess climate change impacts on river runoff. Hydrol Earth Syst Sci Discuss 9:10205-10243

Nakicenovic N and others (2000) Special report on emissions scenarios: a special report of Working Group III of the Intergovernmental Panel on Climate Change. Cambridge University Press, Cambridge

Neumann J, Parpola S (1987) Climatic change and the eleventh-tenth-century eclipse of Assyria and Babylonia.

Editorial responsibility: Balaji Rajagopalan,

Boulder, Colorado, USA
J Near East Stud 46:161-182

Önol B, Semazzi FHM (2009) Regionalization of climate change simulations over the eastern Mediterranean. J Clim 22:1944-1961

> Önol B, Bozkurt D, Turuncoglu UU, Sen OL, Dalfes HN (2014) Evaluation of the twenty-first century RCM simulations driven by multiple GCMs over the eastern Mediterranean-Black Sea region. Clim Dyn 42:1949-1965

Özdoğan M (2011) Climate change impacts on snow water availability in the Euphrates-Tigris basin. Hydrol Earth Syst Sci 15:2789-2803

> Pal JS, Smal EE, Eltahir EAB (2000) Simulation of regionalscale water and energy budgets: representation of subgrid cloud and precipitation processes within RegCM. J Geophys Res 105(D24):29579-29594

Pal JS, Giorgi F, Bi X and others (2007) Regional climate modeling for the developing world: the ICTP RegCM3 and RegCNET. Bull Am Meteorol Soc 88:1395-1409

Reick CH, Raddatz T, Brovkin V, Gayler V (2013) Representation of natural and anthropogenic land cover change in MPI-ESM. J Adv Model Earth Syst 5:459-482

Roeckner E and others (2003) The atmospheric general circulation model ECHAM5. I. Model description. Report No. 349, Max-Planck-Institut für Meteorologie, Hamburg

Stevens B, Marco Giorgetta, Monika Esch, Thorsten Mauritsen and others (2013) The atmospheric component of the MPI-M Earth system model: ECHAM6. J Adv Model Earth Syst 5:146-172

Stewart IT, Cayan DR, Dettinger MD (2005) Changes toward earlier streamflow timing across western North America. J Clim 18:1136-1155

Taylor KE, Stouffer RJ, Meehl GA (2012) An overview of CMIP5 and the experiment design. Bull Am Meteorol Soc 93:485-498

> Voss KA, Famiglietti JS, MinHui L, de Linage C, Rodell M, Swenson SC (2013) Groundwater depletion in the Middle East from GRACE with implications for transboundary water management in the Tigris-Euphrates-Western Iran region. Water Resour Res 49:904-914

- Weiss H (1982) The decline of the Late Bronze Age civilization as a possible response to climate change. Clim Change 4:173-198

> Weiss H, Courty MA, Wetterstrom W, Guichard F, Senior L, Meadow R, Curnow A (1993) The genesis and collapse of third millennium north Mesopotamian civilization. Science 261:995-1004

Zeng X, Zhao M, Dickinson RE (1998) Intercomparison of bulk aerodynamic algorithms for the computation of sea surface fluxes using toga coare and tao data. J Clim $11: 2628-2644$

Submitted: January 23, 2014; Accepted: October 20, 2014

Proofs received from author(s): December 22, 2014 